\title{
Rozwój systemów projektowania i zarządzania w budownictwie drogowym - od Euklidesa i systemów CAD do eLBIM w terenach wrażliwych środowiskowo i społecznie
}

\author{
Joanna Bohatkiewicz, Janusz Bohatkiewicz
}

\author{
EKKOM Sp. z o.o., e-mail: joanna.bohatkiewicz@ek-kom.com \\ Katedra Dróg i Mostów, Wydziat Budownictwa i Architektury, Politechnika Lubelska, \\ e-mail: j.bohatkiewicz@pollub.pl
}

Streszczenie: Artykuł oparty jest na pierwszych doświadczeniach z korzystania z nowych technologii projektowych. W artykule analizuje się możliwość zastosowania odpowiednich narzędzi i metod zarządzania, które mają na celu doskonalszą ochronę środowiska przyrodniczego i ludzi w budownictwie komunikacyjnym. Zastosowanie dwóch technologii: projektowania (BIM) i zarządzania projektem oraz procesem budowy (Lean management) powinno mieć za zadanie poza minimalizacją błędów i kosztów efektywniejsze podejście do spraw ochrony środowiska i ochrony zdrowia ludzi. Autorzy opisują nową koncepcję wskazując na możliwość połączenia systemów BIM oraz Lean management w jeden system, który powinien zostać dodatkowo rozbudowany o zagadnienia środowiskowe (eLBIM) zwłaszcza w przypadkach lokalizacji obiektów budownictwa komunikacyjnego w terenach wrażliwych przyrodniczo i społecznie.

Słowa kluczowe: BIM w budownictwie komunikacyjnym, Lean Management, ochrona środowiska $\mathrm{w}$ budownictwie komunikacyjnym.

\section{Wprowadzenie}

Ostatnie dwudziestolecie w Polsce to czas niezwykle intensywnego rozwoju sieci drogowej. W latach 2011-2014 wybudowano 1804,2 km dróg krajowych, na które przeznaczono ponad 61 mld złotych. Dzięki podjętym inwestycjom infrastrukturalnym, polska sieć dróg w marcu 2015 r. osiągnęła długość $1550 \mathrm{~km}$ autostrad i $1470 \mathrm{~km}$ dróg ekspresowych [11]. Z kolei w latach 2004 - 2013 długość sieci autostrad i dróg ekspresowych w Polsce wzrosła ponad trzyipółkrotnie [13]. Od 2014 roku (w rzeczywistości od 2016 roku) realizowany jest program budowy dróg krajowych na lata 2014-2023. Zakłada on budowę 71,5 km autostrad oraz 2156,4 km dróg ekspresowych i obwodnic. Jest to jeden z największych programów rozwoju sieci drogowej w Europie i na świecie. Doświadczenia ostatnich lat pokazują, że niezbędnym elementem skutecznego zarządzania projektami drogowymi jest przygotowanie oraz realizacja inwestycji z uwzględnieniem punktu widzenia oraz zaangażowaniem wszystkich interesariuszy. Jednym z najistotniejszych elementów na etapie projektowania i wykonawstwa jest współpraca międzybranżowa oraz kooperacja pomiędzy inwestorem, projektantem i wykonawcą. Jest to bardzo ważny aspekt, ponieważ obecnie w Polsce głównie wykorzystywany jest system "Projektuj i buduj", którego kluczowym jest etap projektowania obiektów liniowych i punktowych w sytuacji kiedy liderem jest firma wykonawcza i niezbędne jest współdziałanie zarówno projektantów, specjalistów różnych branż, jak i wykonawców. Taka forma przygotowania i realizacji inwestycji powoduje, że niezbędne jest wykorzystywanie najnowszych zdobyczy w zakresie narzędzi projektowych i informatycznych, metod 
zarządzania wieloma często równoległymi procesami, jak i umiejętność pracy zespołowej (często w zespołach rozproszonych geograficznie).

\section{Od Euklidesa do systemów CAD w projektowaniu dróg}

Nie będzie pomyłką, jeśli za fundament dający podstawy rozwoju przyszłych systemów CAD przyjmie się IV w p.n.e. kiedy to Euklides z Aleksandrii w swoim dziele „Elementy" [22] podał pięć aksjomatów lub tzw. postulatów geometrii przestrzeni, zwanej później euklidesową. Kolejne lata i stulecia przynosiły następne odkrycia i potrzeby [16]. Rewolucja przemysłowa w XVIII-XIX w. przyniosła potrzebę standaryzacji rysunków wykonywanych przez projektantów oraz rozwój prawa patentowego - rys. 1.

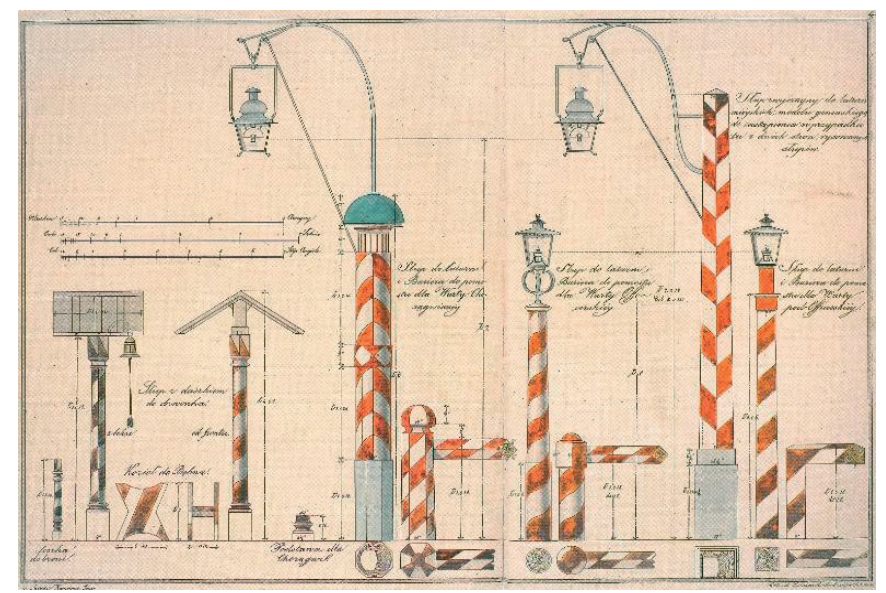

Rys. 1. Przykład rysunku z 1824 r. [14]

W II połowie XX w. powstają pierwsze systemy typu CAD (2D - dwa wymiary). Rozpoczyna się „walka” o szybkość wykonywania projektów, powtarzalność, zautomatyzowanie żmudnych czynności kreślarskich - rys. 2.

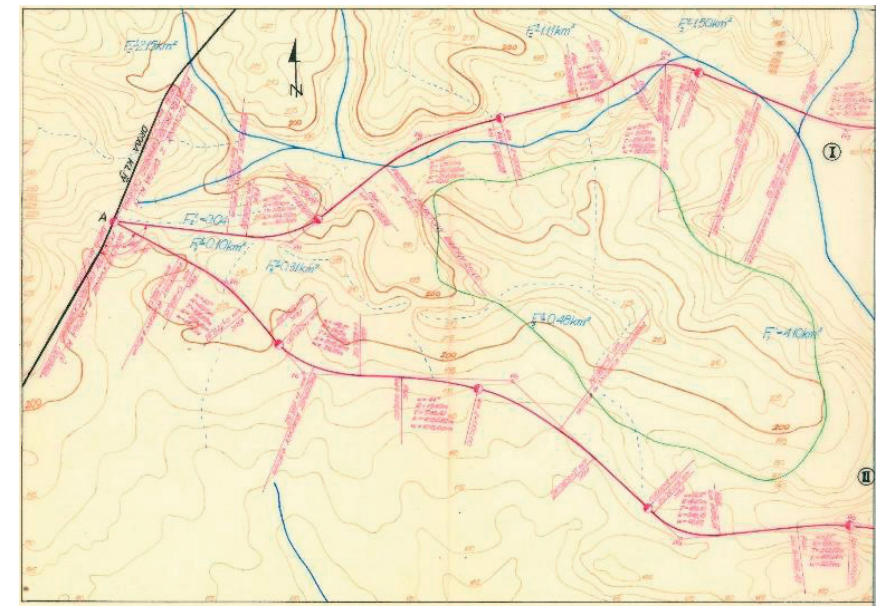

Rys. 2. Przykład ręcznie wykonanego projektu koncepcyjnego drogi w dwóch wariantach (projekt studencki: J. Bohatkiewicz, Politechnika Krakowska, 1985 r.) 
Systemy CAD (2D) z czasem zaczęły wypierać tradycyjne techniki kreślarskie i nastąpiło ich udoskonalanie przez:

- zastąpienie tradycyjnych (ręcznych) metod kreślarskich - następuje szybki zanik zawodu kreślarza,

- przyspieszenie prac nad projektem,

- zwiększenie precyzji rysunku,

- zautomatyzowanie projektowania,

- zmniejszenie ryzyka błędu podczas projektowania i kreślenia,

- możliwość wprowadzania poprawek, zmian, poprawiania błędów,

- zwiększenie możliwości ponownego wykorzystania już wykonanych rysunków, bądź ich fragmentów (biblioteki typowych rozwiązań).

Jednocześnie automatyzacja i komputeryzacja systemów projektowania niesie również za sobą: ograniczenie swobody projektanta, zwiększenie ryzyka błędu przez automatyzm i powtarzalność oraz w wielu sytuacjach syndrom klawisza „enter”, którym można tłumaczyć wiele błędów przez mniej, czy bardziej doskonałe oprogramowanie w rękach mało doświadczonego projektanta.

Wraz z rozwojem systemów projektowania można dostrzec coraz większą liczbę szczegółów związanych z aspektami technicznymi i ekonomicznym, a z czasem również środowiskowymi. W trakcie realizacji pierwszego okresu budowy i przebudowy sieci drogowej z początkiem lat dziewięćdziesiątych XX w. w Polsce powstaje tzw. system ocen oddziaływania na środowisko różnego rodzaju przedsięwzięć w tym również dróg, kolei, lotnisk, linii tramwajowych i innych obiektów komunikacyjnych. W czasie tym dochodzi do paraliżu programu budowy dróg z uwagi na problemy dostosowania projektów budownictwa komunikacyjnego do rosnących wymogów ochrony środowiska. Dodatkowo problemy te powiększa wprowadzona konieczność szerokich konsultacji społecznych projektów inwestycyjnych. Jedną z podstawowych potrzeb staje się odpowiednie przedstawienie graficzne projektów i ich wizualizacji [20]. Do analiz środowiskowych stosowanie są coraz powszechnie zarówno systemy CAD (3D - trzy wymiary), jak i systemy GIS (Geografical Information System). Często efekty pracy tych systemów są ze sobą łączone w celu jak najlepszej wizualizacji problemów geoprzestrzennych - lokalizacja inwestycji i zagadnienia ochrony środowiska).

W praktyce o losie inwestycji od tego czasu zaczyna decydować wrażliwość terenu z punktu widzenia środowiskowego oraz społecznego. Jednocześnie można dostrzec trend coraz szybszego projektowania przy próbach spełnienia zasady „za najniższą cenę, w jak najkrótszym czasie i z jak najmniejszą liczbą błędów”. W wielu sytuacjach zasada ta ma skutek odwrotny i doprowadza do wielu błędów i niepotrzebnych kosztów, a w skrajnych przypadkach nawet do upadku firm.

\section{Rewolucja w projektowaniu i zarządzaniu w budownictwie komunikacyjnym - BIM, LeanBIM, ecoLeanBIM}

Wiele problemów pierwszych dziesięciu lat budowy i przebudowy sieci dróg w Polsce związanych było ze współpracą międzybranżową, kooperacją, jak i błędami wynikającymi z wielu kolizji branżowych (np. kolizja uzbrojenia podziemnego z wyposażeniem drogi, jakimi są np. bariery drogowe, sieci uzbrojenia podziemnego itd.). Problemy te spowodowały poszukiwania firm projektowych oraz wykonawczych w zakresie zarówno narzędzi projektowych, jak i procedur zarządzania. Mocno rozwijająca się w wielu krajach nie tylko europejskich technologia projektowania Building Information Modeling (BIM) 
stała się jednym z potencjalnych narzędzi, które mogą być wykorzystywane w budownictwie infrastrukturalnym. Jednocześnie jest ona określana, jako trzecia rewolucja informatyczna [15]. Technologia ta $\mathrm{z}$ bardzo dużym powodzeniem stosowana jest $\mathrm{w}$ budownictwie kubaturowym (architekturze). W wielu krajach europejskich takich jak np. Wielka Brytania, Norwegia, Szwecja BIM doczekał się pierwszych uregulowań formalnych i nieformalnych [3, 10]. Równocześnie kraje Unii Europejskiej uchwaliły Dyrektywę [7], która wskazuje na możliwość stosowania technologii BIM, cyt. „...W odniesieniu do zamówień publicznych na roboty budowlane i konkursów państwa członkowskie moga wymagać zastosowania szczególnych narzędzi elektronicznych, takich ja narzędzia elektronicznego modelowania danych budowlanych lub podobne.".

Doświadczenia praktyczne w budownictwie infrastrukturalnym w Polsce są jeszcze niewielkie. Praktycznie zaledwie od ponad dwóch lat można zauważyć rosnące zainteresowanie technologią projektowania BIM. W praktyce dyskutowane są możliwości wprowadzenia BIM zarówno w zakresie formalnym (przetargi publiczne), jak również w zakresie praktycznym. Obecnie model wykorzystania BIM zmierza do objęcia zakresem stosowania BIM całego cyklu życia inwestycji, a po realizacji również istniejącego obiektu - rys. 3.

1. Modelowanie sytuacji w stanie istniejącym: podstawowe dane + teren

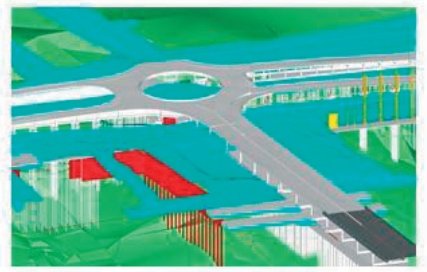

3. Wykonawcy wykorzystują modele w czasie budowy: rozwiązania projektowe, dane o obiektach i zasobach i obmiary, programowanie maszyn budowlanych

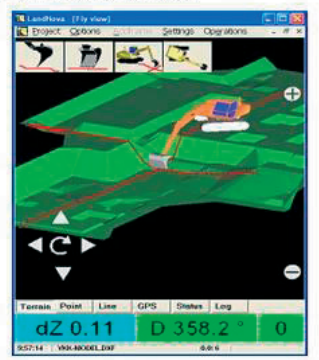

2. Modelowanie nowo projektowanej infrastruktury: różne branże

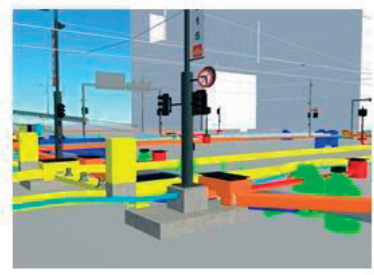

4. Zatwierdzone zmiany są wprowadzane przez wykonawców, następuje weryfikacja modeli wielobranżowych (powykonawczo)

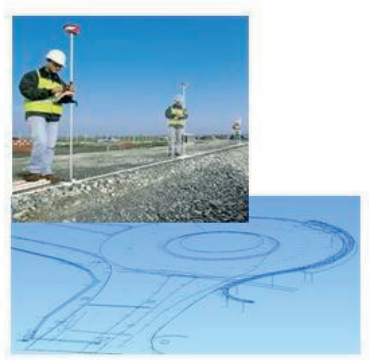

3. Modele wielobranżowe ułatwiają podejmowanie decyzji

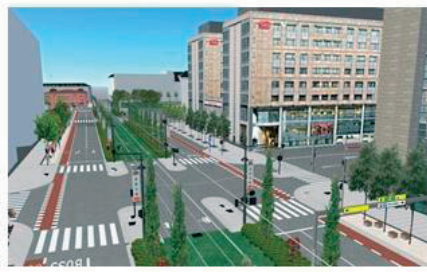

5. Dane do eksploatacji i utrzymania można pozyskać z powykonawczych modeli wielobranżowych

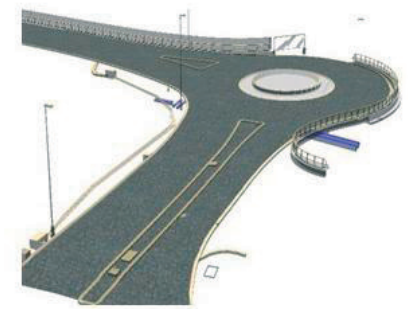

Rys. 3. Model wykorzystania BIM w budownictwie komunikacyjnym [2, 6]

Należy pamiętać, że BIM nie jest jedynie nową technologią projektowania. Jednymi z najczęściej popełnianych błędów jest utożsamianie BIM z zestawem oprogramowania, bądź też projektowaniem 3D. W rzeczywistości są to jedynie narzędzia służące BIM. BIM należy rozpatrywać bardziej w kategorii nowej koncepcji zarządzania i technologii projektowania, którą charakteryzuje m.in. [12]:

- możliwość współpracy wielu branż w jednym środowisku projektowym - tzw. BIM 3D2L, BIM 3D3L (poziom 2L to modele BIM dla każdej branży, które są ko- 
ordynowane przy pomoc specjalnych narzędzi, 3L - model jest zintegrowany obejmujący wszystkie branże - brak jest obecnie odpowiedniego oprogramowania scalającego modele wszystkich branż) [15],

- wykorzystanie oprogramowania umożliwiającego m.in. natychmiastowe identyfikowanie kolizji podczas projektowania poszczególnych elementów projektowanego obiektu,

- przedstawienie wykonanego projektu interesariuszom za pomocą wizualizacji i animacji, co znacząco ułatwia zrozumienie elementów technicznych przez osoby niezwiązane z branżą [20],

- redukcja liczby popełnianych błędów, szczególnie na etapie projektowania, a w sytuacji ich wystąpienia, możliwość natychmiastowego wprowadzenia działań naprawczych w projekcie,

- usprawnienie procesu zarządzania projektem od momentu wysłania oferty do etapu porealizacyjnego.

Punktem zainteresowania autorów artykułu są zarówno aspekty zarządzania projektem i całym procesem inwestycyjnym we wszystkich jego fazach, jak również najistotniejsze elementy praktyczne zastosowania BIM (wpływ na pracę projektanta) z uwzględnieniem uwarunkowań ochrony środowiska. Autorzy uznali, że wyjątkowo newralgicznymi punktami projektowania są obecnie problemy ochrony środowiska oraz zdrowia ludzi. Nieprawidłowe podejście, brak danych, nie wykrycie kolizji z obszarami lub obiektami chronionymi, błędne określenie zasięgów niekorzystnych oddziaływań najczęściej powoduje wydłużanie procesu inwestycyjnego lub nawet jego przerwanie.

Współczesne projektowanie dróg jest realizowane głównie dzięki wykorzystaniu różnorodnego oprogramowania komputerowego, nadal jednak często używany jest płaski model 2D. Jedną z istotniejszych cech BIM w projektowaniu jest możliwość projektowania 3D, parametryzacji elementów projektu, wizualizacji 3D, czy wykrywania kolizji. Projektowanie to jednak jeden $\mathrm{z}$ pierwszych elementów procesu inwestycyjnego i wg autorów możliwie najważniejszy, gdzie może być popełnianych wiele błędów dopiero widocznych na etapie budowy, a w niektórych sytuacjach dopiero w trakcie eksploatacji. Tego typ sytuacje mogą doprowadzać w obszarach wrażliwych do bezpowrotnego zniszczenia chronionej przyrody, czy wprowadzanie dużych uciążliwości dla ludzi. Istotnym elementem jest jednak takie wykonanie projektu, aby produkt końcowy był optymalny i efektywny zarówno z uwagi na uwarunkowania techniczne, ekonomiczne, jak i środowiskowe. W przypadku terenów wrażliwych środowiskowo i społecznie dokładność projektu i wykrywanie kolizji może być szczególnie istotnym celem zastosowania BIM.

Zarówno literatura, jak i dotychczasowe doświadczenia wskazują, że etapem, w którym możliwe jest dokonanie największych oszczędności jest etap projektowania. Zarówno podczas przygotowywania projektu, ale szczególnie podczas przygotowania przedmiarów, kosztorysów i harmonogramowania robót, doboru technologii i materiałów, jak i wykonywania innych prac związanych z zarządzaniem procesem inwestycyjnym można (i powinno się) stosować podejście służące minimalizacji strat na etapie nie tylko samego procesu projektowania, ale także później, wykonawstwa na placu budowy. Dotyczy to również zagadnień ochrony środowiska, gdzie w wielu przypadkach większych inwestycji drogowych konieczne jest prowadzenie systematycznego nadzoru przyrodniczego na budowie. Istnieją miary i arkusze (głownie stosowane w budownictwie kubaturowym) służące ocenianiu projektów pod kątem m.in. późniejszej możliwości ograniczenia kosztów. Są nimi m.in. opracowane przez Building and Construction Authority in Singapore, buildable design appraisal system (BDAS) czy building waste assessment score (BWAS) [2]. 
Z uwagi na możliwe do osiągnięcia oszczędności wynikające z wdrożenia koncepcji BIM w całym cyklu życia projektu, koncepcja ta jest zwykle związana z ideą Lean management (tzw. szczupłego zarządzania), której myślą przewodnią jest dążenie do uproszczeń, redukcji zbędnych nakładów oraz optymalizacji efektów pracy. Lean management jest podejściem systemowym, które polega na identyfikowaniu i usuwaniu wszelkich elementów nieprzynoszących wartości dodanej przedsiębiorstwu takich jak m.in. przestojów, niepotrzebnych działań, nadmiernego gromadzenia zasobów i zapasów. Koncepcja ta, której historia sięga II wojny światowej i japońskiego przemysłu motoryzacyjnego, ma swoje źródła w produkcji, jednak w dzisiejszych czasach znajduje zastosowanie również w innych sektorach gospodarki, w tym w usługach wysokich technologii i działalności eksperckiej [3]. Wykorzystuje szereg narzędzi i technik takich jak m.in. just in time, just on time, kanban, spacer gemba, keizen, jidoka, hoshin kanri, shu-ha-ri czy nemawashi [3].

Koncepcja Lean management znalazła również swoje odzwierciedlenie w technologii BIM:

- Lean management, jako koncepcja oparta o ideę nieustającej poprawy i rozwoju wspiera rozwiązania takie jak BIM, w których jednym z priorytetów jest dążenie do usuwania błędów na możliwie najwcześniejszym etapie,

- wykorzystując metodę 5 Why (5 razy „dlaczego”) [17] może być wykorzystany podczas usuwania błędów projektowych,

- współpraca interesariuszy powoduje nie tylko oszczędności, ale również buduje środowisko otwartej współpracy, budowania zaplecza know-how, dzielenia się wiedzą i doświadczeniami pomiędzy przedstawicielami poszczególnych branż element ten jest niezwykle ważny kiedy możliwa staje się współpraca specjalistów różnych branż w ramach jednego modelu (np. terenu, sieci uzbrojenia itp.),

- usuwanie kolizji współgra z ideą szybkiego rozwiązywania problemów, jak również redukcji kosztów zanim staną się one na tyle wysokie, że rentowność projektu będzie zagrożona,

- bezpośrednie połączenie idei BIM z Lean management uwidacznia się poprzez sformułowaną technikę KanBIM, której celem jest próba zdefiniowania, rozwinięcia oraz przetestowania systemu BIM wdrożonego do przedsiębiorstwa, wspierającego proces planowania produkcji oraz kontroli przeprowadzanej na placu budowy [15],

- funkcjonalności oprogramowania, w szczególności posiadającego funkcjonalności związane z zarządzaniem zespołem, co stanowi o uproszczeniu procedur komunikacyjnych związanych m.in. z delegowaniem zadań. Również kanały komunikacyjne wykorzystywane w BIM znacząco usprawniają ten proces, dzięki czemu koszty projektu w efekcie są niższe.

Korzyści z BIM należy poszukiwać w rosnącej produktywności, efektywności działania, tworzeniu wysokiej jakości i wartości dodanej dla klienta, uzyskiwanie przewagi konkurencyjnej [4]. Wartością dodaną implementacji BIM, w szczególności zgodnie z podejściem Lean BIM staje się także zwiększona świadomość pracowników związana z zarządzaniem procesowym, ideą ciągłego doskonalenia się, jak również „zleanowanie” pozostałych procesów w firmie, pozornie mniej zależnych od działań projektowych (np. marketing, sprzedaż, zarządzanie zasobami ludzkimi, obsługa klienta). W celu uzyskania optymalnej efektywności tworzy się w tym celu m.in. bazę danych project support information (PSI), zawierającą dane z obszarów: finansów, marketingu, administracji i zarządzania przetargami. Wdrożenie BIM powinno przebiegać zgodnie $\mathrm{z}$ podejściem bottom-up z jednoczesnym wyraźnie komunikowanym wsparciem ze strony kadry zarządzającej różnych szczebli. Zmniejsza to opór przeciw zmianie, ułatwia zrozumienie konieczności 
wprowadzenia zmian, ułatwia proces utożsamiania celów jednostki z celami organizacji, wzmaga zaangażowanie, zapewnia nie tylko rozwój technologiczny przedsiębiorstwa, ale również rozwój kapitału ludzkiego poprzez nowe kompetencje ludzi m.in. związane z nowym oprogramowaniem. BIM to także zarządzanie informacją, która powinna cechować się: łatwością przyswajania przez odbiorcę (np. projektanta), tj. zrozumiałością, prowadzić do optymalizacji i redukcji kosztów, być uprzednio przefiltrowana i zsyntezowana, a więc zawierać jedynie niezbędne elementy, być łatwo dostępna (np. dzięki internetowi i terminalom wifi - wireless terminals), możliwa do zarządzania za pomocą narzędzi ICT dostosowanych do odpowiednich grup docelowych [5].

W przypadku przejścia do fazy wykonywania robót budowlanych z powodzeniem może być wdrażana w technologii BIM idea Lean management, która powoduje, iż projekty mogą być wykonywane w sposób bardziej efektywny, optymalnie wykorzystując zasoby, powodując mniejsze koszty inwestycji i minimalizując liczbę ewentualnych zmian na etapie budowy, jak również wspierając proces zarządzania ryzykiem w projekcie [16]. Zagadnienie, jakim jest BIM, stanowi w swej naturze obszar interdyscyplinarny, łączący nauki techniczne $\mathrm{z}$ naukami ekonomicznymi i innymi.

Doświadczenia w zakresie stosowania zarówno BIM, jak i Lean management w zakresie poznania możliwości uzyskania efektu synergii, połączenia elementów specyficznych dla poszczególnych koncepcji oraz ich praktycznego zastosowania stanowi jeden z obszarów zainteresowań badawczych [14]. Wśród identyfikowanych strat i nieefektywności w okresie realizacji inwestycji należy wyszczególnić m.in.: czas oczekiwania np. na materiały, duplikowanie zadań, straty materiałowe, koszty transportu, magazynowania, błędów i defektów w projektach, wydłużania łańcucha dostaw i wynikające ze skomplikowania procesów w firmie, wydłużony czas realizacji, błędy jakościowe, błędy komunikacyjne i brak efektywnej komunikacji, koszty zwiększonej fluktuacji pracowniczej, nieoptymalne warunki pracy, występowanie wypadków, powtórne wykonywanie zadań, wykonywanie zadań jedne po drugich zamiast jednocześnie (zadania równoległe), brak optymalizacji kosztowej i procesowej. Straty te mogą powodować w konsekwencji trudności w utrzymaniu zasobów, następnie utratę klientów wraz z trudnością w pozyskaniu nowych, a kolejno spadek obrotów przedsiębiorstwa, zmniejszenie zysku, bądź też wypracowanie straty oraz utratę pozycji konkurencyjnej na rynku [1], a w ostateczności także utratę płynności finansowej. Na poziomie makroekonomicznym mogą one wpływać na pogorszenie koniunktury gospodarczej, problemy środowiskowe i nieosiągnięcie celów zrównoważonego rozwoju. Połączenie BIM z Lean management wskazuje, iż możliwe jest osiągnięcie wymiernych korzyści z tytułu wdrożenia tej technologii projektowania i procesu w firmie wykonawczej. Ten rodzaj połączenia powinien dawać nowe możliwości i przewagę firmom działającym w systemach „Projektuj i buduj”, czy również zapowiadanym do stosowania przez zarządców dróg systemom optymalizacji i budowy oraz budowy i dalszego utrzymania drogi w ramach długoterminowych kontraktów.

W przypadku stosowania LeanBIM w terenach wrażliwych przyrodniczo i społecznie możliwa staje się identyfikacja niekorzystnych oddziaływań i ich wpływ na te tereny praktycznie od momentu wykonywania koncepcji rozwiązania aż po etap utrzymywania obiektu. Obecne zarządzanie stanem środowiska w otoczeniu dróg ogranicza się do wykonywania pojedynczych prognoz uzależnionych od etapu procesu inwestycyjnego. Podczas przygotowywania inwestycji wykonywane opracowanie środowiskowe (karta informacyjna przedsięwzięcia, raport o oddziaływaniu przedsięwzięcia na środowisko) odnosi się do stanu istniejącego a także wskazuje efekty oddziaływań w określonych horyzontach czasowych (głównie 10-15 lat). Po oddaniu inwestycji drogowych często wykonywane są jeszcze opracowania środowiskowe (analiza porealizacyjna, przeglądy ekologiczne, monitoringi), 
których celem jest określenie faktycznych oddziaływań w trakcie eksploatacji funkcjonującego obiektu. Pomimo zaleceń, aby system opracowań środowiskowych tworzył proces, w praktyce jest to jednak mało realne do realizacji. Problemami w tym przypadku są m.in.: brak odpowiednich narzędzi informatycznych, gromadzenie często rozproszonych danych i ich przetwarzanie oraz brak jednolitego systemu tworzącego proces (od pomysłu do inwestycji do zarządzania istniejącym obiektem). Zdaniem autorów rozwiązanie tego problemu może nastąpić po uzupełnieniu systemu LeanBIM o elementy środowiskowe zwłaszcza w miejscach wrażliwych środowiskowo i społecznie. Takie rozwinięcie LeanBIM pozwoli na utworzenie pełnego i kompleksowej koncepcji (systemu) ecoLeanBIM (proponowana nazwa przez autorów: eLBIM), który umożliwi poza zagadnieniami technicznymi wprowadzenie pełnego prowadzenia (zarządzania) inwestycji, a później istniejącego obiektu pod względem ochrony środowiska. Wymagało to jednak będzie uzupełnienia narzędzi informatycznych o elementy środowiskowe (warstwy środowiskowe, jako element dla którego mogą być wykazywane kolizje z innymi obiektami) oraz ujednolicenia procedur pozyskiwania i przetwarzania danych środowiskowych. Dotyczy to zwłaszcza miejsc i sytuacji, gdzie obserwowana jest duża wrażliwość środowiska i np. znaczna zmienność ruchu drogowego powodująca znaczące negatywne oddziaływania. Do stworzenia systemu eLBIM niezbędne jest jednak prowadzenie dalszych analiz zarówno teoretycznych, jak i praktycznych (w warunkach rzeczywistych). Analizy te powinny obejmować przede wszystkim (przy założeniu, że priorytetowo traktowane są obszary wrażliwe przyrodniczo i społecznie) trzy etapy:

- Planowania i projektowania inwestycji. Zintegrowanie zagadnień środowiskowych z projektowaniem rozwiązań drogowych zarówno w sferze zagadnień technicznych, jak i kosztowych. W przypadku systemów „Projektuj i buduj” istotne będzie określenie możliwości wykonywania obiektów w określonej technologii i określonych porach doby i/lub roku.

- Wykonywania robót. Dotyczy przede wszystkim prowadzenia nadzoru przyrodniczego oraz nadzoru związanego z zakłóceniami dla ludzi (np. roboty w porze dnia i nocy w terenach chronionych akustycznie) $\mathrm{w}$ trakcie budowy $\mathrm{z}$ uwzględnieniem tego w harmonogramach i kosztorysach - tzw. BIM 4D (BIM 3D+harmonogram), BIM 5D (BIM 4D+koszty wraz z budżetem).

- Utrzymania i eksploatacji. Na etapie tym możliwe jest prowadzenie monitoringu obiektu z uwagi na niekorzystne oddziaływania. W ramach systemu powinny zostać uwzględnione wszelkie działania obowiązkowe zarządcy drogi, jak np. wyniki i zalecenia: analizy porealizacyjnej, przeglądów ekologicznych, programów ochrony przed hałasem itp.

Wprowadzenie eLBIM poza typowymi zyskami BIM i procesów Lean management pozwolą na pełne zarządzanie problematyką ochrony środowiska i zrównoważonego rozwoju. W tabl. 1 przedstawiono możliwe obszary uzyskiwania oszczędności dzięki połączeniu BIM z Lean management i zagadnieniami ochrony środowiska. 
Tabela 1. Przykładowe obszary uzyskiwania oszczędności dzięki zastosowaniu eLBIM

\begin{tabular}{lll}
\hline Element charakterystycz- & Obszary oszczędności & Uzyskiwana oszczędność
\end{tabular}
ny dla koncepcji eLBIM

\begin{tabular}{ll}
\hline Współpraca wielobranżo- & Współpraca w tym samym środowisku \\
wa w projektowaniu za & informatycznym usprawni udostępnianie, \\
pomocą wspólnego & przesyłanie, edytowanie, korektę danych w \\
oprogramowania i modelu & projekcie. Daje również możliwośc pełnego \\
danych & zarządzania projektem z włączeniem \\
& wykonawcy robót (w systemach „Projektuj \\
& i buduj) oraz inwestora (szybki podgląd \\
& postępu prac i ewentualne korekty).
\end{tabular}

Używanie oprogramowa- Szybkie wykrywanie kolizji umożliwi nia umożliwiającego szybkie wykrywanie kolizji
Szybkie wykrywanie kolizji umożliwi
wprowadzenie niezbędnych poprawek projektowych już na etapie projektu nie zaś na etapie budowy, kiedy poniesiono już wydatki materiałowe, wynagrodzeń, surowców, uzyskano niezbędne zezwolenia, postanowienia i decyzje administracyjne. Wykrywanie kolizji z terenami wrażliwymi przyrodniczo i społecznie pozwoli na wybór optymalnych lokalizacji i rozwiązań.
Oszczędność czasu pojedynczych pracowników, oszczędność czasu niezbędnego do wykonania projektu, ograniczenie czasu oczekiwania, ograniczenie kosztów materiałów, dojazdów (delegacji), dobór optymalnych materiałów i technologii.

Oszczędność kosztów realizacji inwestycji, w tym: oszczędność kosztów transportu materiałów i surowców, oszczędność materiałów, surowców, półproduktów, a także w przypadku znaczących kolizji z terenami wrażliwymi przyrodniczo i społecznie optymalizacji kosztów poszukiwania nowych rozwiązań.

Redukcja liczby popełnia- Minimalizacja liczby błędów projektowych nych błędów zwiększa efektywność działania, powoduje, że projekt może być realizowany zgodnie z harmonogramem i budżetem oraz bez strat dla środowiska.

Oszczędność czasu, kosztów i potencjalnych zniszczeń cennych przyrodniczo stanowisk i kosztów społecznych.

Oszczędność kosztów pośrednich i bezpośrednich, oszczędność czasu, oszczędność materiałów, minimalizacja strat środowiskowych. oszczędności w zakresie m.in.: przepływu
informacji, wykorzystywanych kanałów komunikacyjnych, ograniczenia kosztów bezpośrednich i pośrednich.

Usprawnienia procesu zarządzania projektami powoduje, iż możliwe jest osiągnięcie oszczędności w zakresie m.in.: przepływu
informacji, wykorzystywanych kanałów
Brak dodatkowych kosztów przetwarzania rozproszonych danych.
Usprawnienie procesu zarządzania projektem i realizacją obiektu inwestycyjnego $\mathrm{i}$ budowy $\mathrm{z}$ pełnym monitoringiem inwestycji i obiektu (planowanie i projektowanie, budowa, utrzymanie i eksploatacja), którego efektem jest minimalizacja strat w środowisku.

Wykorzystywanie jednego modelu danych od obiektu z danymi o stic środowiska i niekorzystnych oddziaływaniach

\section{Podsumowanie}

Współczesne projektowanie i wykonawstwo robót wymaga stosowania zarówno odpowiednich narzędzi projektowych, jak i procesów zarządzania. Rozwijana w świecie od wielu lat technologia projektowania BIM w architekturze powoli zaczyna zyskiwać zwolenników i staje się potrzebą w budownictwie komunikacyjnym. Coraz częstsze połączenie projektowania z wykonywaniem robót w systemach „Projektuj i buduj” wymaga jednak o wiele bardziej precyzyjnych i powiązanych ze sobą narzędzi. Takie powiązanie spełniające jednocześnie kilka kryteriów (minimalizacja błędów projektowania, wczesne wykrywanie kolizji na etapie projektowania, dobór optymalnych technologii i materiałów, harmonogramowanie oraz określanie kosztów itd.) spełnia powiązanie zarówno technologii BIM $\mathrm{z}$ procesami Lean management $\mathrm{w}$ jeden system LeanBIM. Jednocześnie konieczność 
uwzględnienia złożonych problemów ochrony środowiska na wszystkich etapach procesu inwestycyjnego prowadzi do wniosku, że system LeanBIM powinien uwzględniać jak najszerzej te problemy. Proponowana koncepcja eLBIM powiązania technologii projektowania, procesów zarządzania i zagadnień ochrony środowiska może sprawdzać się szczególnie w terenach wrażliwych środowiskowo i społecznie, gdzie liczba danych, uzgodnień, wariantów rozwiązań tworzy niekiedy największą barierę i koszty nie tylko podczas przygotowania inwestycji, ale i później jej utrzymania i eksploatacji. Koncepcja ta wymaga jednak szeregu badań o charakterze teoretycznym i praktycznym, a także rozwoju narzędzi informatycznych na poziomie BIM 3D2L, a najlepiej BIM 3D3L. Należy jednocześnie mieć na względzie to, że wprowadzanie BIM z przekonaniem, że obecnie jeden program komputerowy spełni wszystkie opisywane wymagania będzie prowadziło do strat i wydłużania procesu inwestycyjnego dla firm projektowych i wykonawczych.

\section{Literatura}

1 Arayici Y., Coates P., Koskela L., Kagioglou M., Usher C., O’Really K. Technology adoption in the BIM implementation of lean architectural practice. Elsevier 2010.

2 Bohatkiewicz J. Nowe tendencje i trendy $w$ projektowaniu dróg. Seminarium SITK Oddziat w Białymstoku. Augustów, 2010 r. (materiały niepublikowane)

3 Building Information Modelling. Industrial strategy - government and industry in partnership. HM Government, 2012.

4 Bhargav D., Kubler S., Framling K., Koskela L. Opportunities for enhanced lean construction management using Internet of Things standards. Elsevier 2015.

5 Blikle A. J. Doktryna jakości. Rzecz o skutecznym zarządzaniu. Wydawnictwo HELION, Gliwice 2014, 517.

6 Thor Sigurd Thorsen, Merete Tøndel. Documented effects of model-based road projects. Effects by using Handbook 138 Model Data. Statens Vegvesen Vegdirektoratet, Vianova Systems. Novapoint Brukermøte. Haugesund, 2014 (materiały niepublikowane)

7 Dyrektywa Parlamentu Europejskiego i Rady 2014/24/UE z dnia 26 lutego 2014 r. w sprawie zamówień publicznych (Dz.U.UE.L.2014.94.65)

8 Ekanayake L. L., Ofori G. Building waste assessment score: design-based tool. Elsevier 2004.

9 Neo R. B., Koh T. J. Accounting for waste in construction, [in:] Yeo K. T. Proc. I ${ }^{\text {st }}$ International Conference on Construction Project Management, Singapore, 1995.

10 Guidelines Manual V770 Model Basis Requirements for basic data and models. Norwegian Public Roads Authority (NPRA), 2014. (original: Veiledning Håndbok V770 Modellgrunnlag Krav til grunnlagsdata og modeler).

11 Informacja dotycząca stanu realizacji Programu Budowy Dróg Krajowych na lata 2011-2015 raport na 2014 r., www.mib.gov.pl/2-program_budowy_drog_krajowych.htm (stan na marzec 2016).

12 Liu Z., Osmani M., Demian P., Baldwin A. A BIM-aided construction waste minimisation framework, Elsevier 2015.

13 Program Budowy Dróg Krajowych na lata 2014 - 2023 (z perspektywą do 2025 r.), Załącznik do uchwały nr 156/2015 Rady Ministrów z dn. 8 września 2015.

14 Szlaki trakty autostrady. GDDKiA, Warszawa, 2009.

15 Tomana A. BIM. Innowacyjna technologia w budownictwie - podstawy, standardy, narzędzia. Kraków, 2015.

16 Weisberg David E. The engineering design revolution w http://www.cadhistory.net/ (marzec 2016 r.).

17 Sacks R., Bhargav A. D., Koskela L., Owen R. Analysis framework for the interaction between lean construction and building information modelling, [in:] Proc. for the 17th Annual Conference of the International Group for Lean Construction, 15th-17th July 2009, National Pingtung University of Science and Technology, Taiwan. 
18 Sacks R. BIM and Lean Construction. Can BIM remove waste from construction processes?, Tekla European BIM Forum 2014, [in:] http://www.tekla.com/de/bim-forum2014/presentations/sacks.pdf (stan na marzec 2016).

19 Zou Y., Kiviniemi A., Jones S. W. A review of risk management through BIM and BIM-related technologies. Elsevier 2015.

20 Żakowska L. Wizualizacja w projektowaniu dróg. Aspekty bezpieczeństwa i estetyki. Monografia, Zeszyty Naukowe Politechniki Krakowskiej, seria Architektura nr 44, Politechnika Krakowska, 2001.

$21 \mathrm{http}: / /$ www.lifetime-reliability.com/tutorials/lean-management-methods/How_to_Use_the_5Whys_for_Root_Cause_Analysis.pdf (stan na marzec 2016).

22 https://pl.wikipedia.org/wiki/Elementy (stan na marzec 2016).

\title{
Development of design and management systems in road construction industry - from Euclid and CAD systems to eLBIM in the areas environmentally and socially sensitive
}

\author{
Joanna Bohatkiewicz, Janusz Bohatkiewicz \\ EKKOM Sp.z o.o., e-mail: joanna.bohatkiewicz@ek-kom.com \\ Department of Roads and Bridges, Faculty of Civil Engineering and Architecture, \\ LublinUniversity of Technology,e-mail: j.bohatkiewicz@pollub.pl
}

\begin{abstract}
This article, in spite of being largely theoretical, is based on the first experience with the use of new technology projects. The article examines the possibility of using appropriate tools and management methods, which aim to better protect the natural environment and people in civil engineering. The use of two technologies: design (BIM) and project management and management of a construction process (Lean Management) should result in creating an effective approach for the protection of the environment and human health, in addition to errors minimisation and costs reduction. The authors suggest in theoretical considerations the possibility of merging BIM and Lean Management into one system, which should be further extended to the environmental issues (eLBIM), especially in cases of civil engineering structures located in the areas environmentally and socially sensitive.
\end{abstract}

Keywords: BIM in civil engineering, Lean Management, environmental protection in civil engineering. 
